\title{
Rooting Potential of Mini-Cuttings for the Production of Potato Plantlets
}

\author{
Dilson Antônio Bisognin*, Maurício Guerra Bandinelli, Paula Kielse, Hardi Fischer \\ Department of Plant Sciences, Federal University of Santa Maria, Santa Maria, Brazil \\ Email: ${ }^{*}$ dilson.bisognin@ufsm.br
}

Received 9 January 2015; accepted 10 February 2015; published 15 February 2015

Copyright (C) 2015 by authors and Scientific Research Publishing Inc.

This work is licensed under the Creative Commons Attribution International License (CC BY). http://creativecommons.org/licenses/by/4.0/

c) (i) Open Access

\section{Abstract}

The production of mini-tubers under soilless cultivation system increased the availability of pathogen-free seed potatoes. The objective of this study was to evaluate the rooting capability of mini-cuttings of potato clones as a function of the irrigation solution and the physiological age of the mother plant, under soilless cultivation system. Potato mini-cuttings were collected from young and mature plants of the cultivars Asterix and Macaca and the advanced clone SMINIA 793101-3. The young plants were newly acclimatized individuals and the mature plants were at the stage of producing mini-tubers. In the first experiment, mini-cuttings originating from summer pruning of mature plants were grown under closed soilless cultivation system irrigated with a nutrient solution developed for the production of potato mini-tubers and a solution comprised of tap water only. The experiment was conducted in a $3 \times 2$ factorial arrangement (clones and irrigation solutions) in the complete random design with four replicates of $\mathbf{1 5}$ mini-cuttings. In the second experiment, the young and mature mini-cuttings were established under a closed soilless cultivation system irrigated with nutrient solution. The experiment was conducted in a $3 \times 2$ factorial arrangement (clones and physiological age of the mother plant) in the complete random design with four replicates of 15 mini-cuttings. In both experiments, the percentage of rooting and survival of mini-cuttings, number of roots and length of the longest root were assessed at 21 days of cultivation. Potato mini-cuttings can be rooted under closed soilless cultivation system irrigated with nutrient solution or tap water. Mini-cuttings of young plants have higher rooting capability compared to the ones taken from mature plants. The loss of rooting capability depends upon the potato cultivar.

\section{Keywords}

Solanum tuberosum L., Nutrient Solution, Physiological Age, Mini-Clonal Hedge, Mini-Tuber Production

\footnotetext{
${ }^{*}$ Corresponding author.

How to cite this paper: Bisognin, D.A., Bandinelli, M.G., Kielse, P. and Fischer, H. (2015) Rooting Potential of Mini-Cuttings for the Production of Potato Plantlets. American Journal of Plant Sciences, 6, 366-371.
} 


\section{Introduction}

Potato (Solanum tuberosum L.) cultivation is characterized by a high yield potential and ensures greater use of food production areas. However, the use of seed potatoes infected by fungi, bacteria and/or viruses reduces the potential yield of the crop as a result of the progressive degeneration caused by such pathogens during successive field generations. This requires the regular renewal of the seed potatoes used in crop implementation [1].

In Brazil, the production of mini-tubers under soilless cultivation system has enabled the increased supply of pathogen-free seed potatoes. This system allows greater plant health and proper nutrition control [2], in addition to increased productivity of mini-tubers per area unit [3]-[5]. However, the plantlets used to produce mini-tubers are cultivated in vitro, whose cost of production is high, especially because of specialized equipment and reagent requirements [6].

Cutting is seen as an alternative to reduce the amount of plantlets that are cultivated in vitro and then used in the production of potato mini-tubers. This technique consists in rooting the mini-cuttings from plants at the stage of producing seed potatoes [7] or from newly acclimatized plants [8]; it also uses detached shoots of seed tubers [9].

Several factors may influence the adventitious rooting of potato mini-cuttings, particularly the nutritional status of the plant and the degree of juvenility of propagules [9]. Mineral nutrition consists of macro and micronutrients that optimize the nutritional status of the plants, enabling greater availability of endogenous auxins, carbohydrates and metabolic compounds that can promote adventitious rooting [10]. The degree of juvenility of propagules can also contribute to rhizogenesis, as a result of the morphological and physiological changes that occur during plant development [11]. Typically, propagules from young plants have higher rooting ability compared to those from mature plants.

The aim of this study was to assess the rooting capability of mini-cuttings of potato clones as a function of irrigation solution and physiological age of the mother plant, under a soilless cultivation system.

\section{Methodology}

\subsection{Production of Mini-Cutting}

Two experiments were conducted in a netted greenhouse, covered with 150-micron polyethylene film and protected with an anti-aphid net along its sidewalls. In both experiments, the propagation material consisted of potato shoot mini-cuttings (1.5 to $2.0 \mathrm{~cm}$ in length) and a leaf during the initial expansion phase.

The mini-cuttings were taken from young and mature mother plants, depending on each experiment, using the cultivars Asterix and Macaca and the advanced clone SMINIA793101-3. For terminological simplification purposes, they will be referred to as clones.

The young plants were newly acclimatized individuals, and the mature plants were at the stage of beginning of tuberization (about 30 days after transplanting). Both mother plants were obtained from micropropagation and were acclimatized under a soilless cultivation system developed for this purpose [12] and adapted for the rooting of mini-cuttings.

\subsection{Soilless System}

The soilless cultivation system employed in mini-cutting rooting [12] consists of a polyethylene tray $(55.0 \times$ $34.0 \times 15.0 \mathrm{~cm}$ ) containing a $7.0 \mathrm{~cm}$ layer of mid-sized gravel (for ease of drainage of the irrigation solution) and a fine polyethylene net which separates the substrate and the gravel. The substrate was formed from a 5.0 $\mathrm{cm}$ layer of coarse sand (particles between 1.0 and $3.0 \mathrm{~mm}$ diameter) where the mini-cuttings of young and mature plants were established $(2.0 \times 2.0 \mathrm{~cm}$ spacing $)$. Irrigation was performed every two hours with the aid of a digital timer and a low-flow pump to enable total soaking of the substrate. The surplus solution was drained at every irrigation through two holes: one at the base and one near the top edge of the tray, thus avoiding overflow.

\subsection{Nutrient Solution}

Two solutions were tested to irrigate the mini-cuttings. The same nutrient solution used for mini-tuber production and tap water. The nutrient solution was formulated with the following macronutrient composition (in mg/L): $505.50 \mathrm{KNO}_{3} ; 204.15 \mathrm{KH}_{2} \mathrm{PO}_{4} ; 308.0 \mathrm{MgSO}_{4}$ and $724.00 \mathrm{Ca}\left(\mathrm{NO}_{3}\right)_{2}$ and the following micronutrients (in 
$\mathrm{mg} / \mathrm{L}$ ): $0.07 \mathrm{Na}_{2} \mathrm{MoO}_{4} ; 1.50 \mathrm{H}_{3} \mathrm{BO}_{3} ; 0.25 \mathrm{CuSO}_{4} ; 0.20 \mathrm{MnSO}_{4}$ and $0.10 \mathrm{ZnSO}_{4}$, as well as $1.0 \mathrm{mg} \cdot \mathrm{L}^{-1} \mathrm{Fe}$ added as chelate iron $6 \%$. Throughout the experiment, electrical conductivity (EC) and $\mathrm{pH}$ of the nutrient solution were maintained at $1.0 \mathrm{dS} / \mathrm{m}$ and $6.5 \pm 2$, respectively. For the tap water used to irrigate the mini-cuttings, $\mathrm{pH}$ was 6.4 and electrical conductivity was $0.56 \mathrm{dS} / \mathrm{m}$, and it contained the following mineral residues (in $\mathrm{mg} / \mathrm{L}$ ): $1.0 \mathrm{~K}^{+}, 2.0$ $\mathrm{Ca}^{2+} ; 0.40 \mathrm{Mg}^{2+}, 5.0 \mathrm{Na}^{+}$, and $0.10 \mathrm{~B}$; the other nutrients were below the detection limit.

\subsection{Experimental Design}

In the first experiment, apical mini-cuttings of mature plants of three potato clones were rooted under closed soilless cultivation system irrigated with nutrient solution and tap water. The experiment was conducted in the late spring of 2007 in a $3 \times 2$ factorial arrangement (clones and irrigation solutions) in the complete random design with four replicates of 15 mini-cuttings.

In the second experiment, apical mini-cuttings obtained from young and mature potato plants were established under closed soilless cultivation system irrigated with nutrient solution. The experiment was conducted in the fall of 2008, in a $3 \times 2$ factorial arrangement (clones and physiological age of the mother plant) in the complete random design with four replicates of 15 mini-cuttings.

\subsection{Data Collection}

In both experiments, the percentage of rooting and survival of the mini-cuttings, the number of roots and the length of the longest root $(\mathrm{cm})$ were assessed at 21 days of cultivation. Percentage data on the survival and rooting of the mini-cuttings were calculated relative to the total number of mini-cuttings. The number of roots and the length of the longest root were calculated taking into consideration only the rooted mini-cuttings.

\subsection{Data Analysis}

The data were subjected to analysis of variance for the $\mathrm{F}$ test and the means were compared by the Duncan test at $5 \%$ probability of error, with the aid of the statistical program SOC-NTIA/EMBRAPA [13]. To satisfy the assumptions of the analysis of variance, count data were transformed to a new scale, resulting in data that are expected to satisfy the assumptions of additivity, normality, and homogeneity of variance.

\section{Results and Discussion}

\subsection{First Experiment}

In the first experiment, there was a significant interaction $(\mathrm{p}<0.05)$ between clones and irrigation solutions for the percentages of survival and rooting, number of roots and length of the longest root. For these variables, the best results occurred with the clones Macaca and SMINIA793101-3, both with the nutrient solution and tap water (Table 1). The clone Asterix was inferior compared to the others for all variables analyzed, and high mortality rates were observed for the mini-cuttings. There was $100 \%$ mortality in the nutrient solution treatment, and only $16.6 \%$ of the mini-cuttings remained alive when tap water was used.

\subsection{Second Experiment}

In the second experiment, the percentage of rooting, number of roots and length of the longest root were influenced by the physiological age of the mother plants. For these variables, young mini-cuttings proved superior to mature mini-cuttings (Table 2). The treatment with young mini-cuttings showed $87.2 \%$ of rooting, an increase of $78.3 \%$ compared to the treatment with mature mini-cuttings (8.9\%). Lower rooting capacity of mini-cuttings from mother plants with advanced physiological age had already been observed in potatoes [8] and woody species [14]-[16], which shows that the juvenility of the propagation material can determine the success of adventitious rooting.

\subsection{Mini-Cutting Age and Rate of Survival}

For the survival of the mini-cuttings, a significant interaction was observed between the physiological age of the mother plants and the clones. For all the assessed clones, mini-cuttings from young plants had a higher rate of 
Table 1. Percentage rates of survival and rooting, average number of roots and average length of the longest root of minicuttings of mature plants of three potato clones irrigated with two irrigation solutions.

\begin{tabular}{|c|c|c|c|c|c|c|c|c|}
\hline \multirow{2}{*}{ Clones } & \multicolumn{2}{|c|}{ Survival (\%) } & \multicolumn{2}{|c|}{ Rooting (\%) } & \multicolumn{2}{|c|}{ Number of roots } & \multicolumn{2}{|c|}{$\begin{array}{l}\text { Length of longest } \\
\text { root }(\mathrm{cm})\end{array}$} \\
\hline & $\mathrm{TW}^{*}$ & NS & TW & NS & TW & NS & TW & NS \\
\hline Масаса & $54.9 \mathrm{aA}^{* *}$ & $63.3 \mathrm{aA}$ & $44.9 \mathrm{aA}$ & 61.6 aA & $7.8 \mathrm{aA}$ & $5.9 \mathrm{aA}$ & $4.1 \mathrm{aA}$ & $4.0 \mathrm{aA}$ \\
\hline SMINIA793101-3 & 64.9 aA & $81.6 \mathrm{aA}$ & 49.9 aA & $68.3 \mathrm{aA}$ & $5.8 \mathrm{aA}$ & $5.5 \mathrm{aA}$ & $3.1 \mathrm{aA}$ & $3.4 \mathrm{aA}$ \\
\hline Asterix & $16.6 \mathrm{bA}$ & $0.0 \mathrm{bB}$ & $13.3 \mathrm{bA}$ & $0.0 \mathrm{bB}$ & $3.3 \mathrm{bA}$ & $0.0 \mathrm{bB}$ & $1.0 \mathrm{bA}$ & $0.0 \mathrm{bB}$ \\
\hline CV (\%) & \multicolumn{2}{|c|}{27.7} & \multicolumn{2}{|c|}{30.8} & \multicolumn{2}{|c|}{23.6} & \multicolumn{2}{|c|}{22.3} \\
\hline
\end{tabular}

*Irrigation solution: TW = tap water and NS = nutrient solution. ${ }^{* *}$ Means followed by the same letter (lowercase vertically and uppercase horizontally) in each of the variables assessed, do not differ by the Duncan test at $\mathrm{p}<0.05$ of probability.

Table 2. Rooting percentage, average number of roots and average length of the longest root of mini-cuttings of three potato clones with different physiological ages.

\begin{tabular}{cccc}
\hline Physiological age & Rooting (\%) & Number of roots & Root length $(\mathrm{cm})$ \\
\hline Young & $87.2 \mathrm{a}^{*}$ & $4.4 \mathrm{a}$ & $3.2 \mathrm{a}$ \\
Mature & $8.9 \mathrm{~b}$ & $1.3 \mathrm{~b}$ & $1.2 \mathrm{~b}$ \\
CV (\%) & 21.6 & 20.3 & 25.1 \\
\hline
\end{tabular}

*Means followed by the same letter do not differ by the Duncan test at $\mathrm{p}<0.05$ of probability.

survival, differing significantly from the mature mini-cuttings (Table 3). The treatment consisting of young mini-cuttings of the clone Asterix showed a survival rate of $86.7 \%$ compared to only $8.3 \%$ for the treatment comprised of mature mini-cuttings. This shows that the survival of potato mini-cuttings is strongly influenced by the physiological age of the mother plants and by the clones, i.e. both the genetic and physiological age affect the capability of mini-cutting rooting.

The differences in the physiological ages of the buds were described as cyclophysis, which is an important source of phenotypic variation, which is still little explored [17]; it is also known as epigenetic inheritance across generations of vegetative propagation [18]. In the present study, potatoes experienced the effect of cyclophysis, which was variable across clones. This shows that the clones which were less affected by cyclophysis can be used successfully to produce plantlets from mini-cuttings of mature plants.

\subsection{Advantages of the Mini-Cutting Technique}

Under the soilless cultivation system used to produce potato mini-tubers, there is excessive shoot growth of potato plants, which can be controlled by pruning [19]. The removed apices showed high health and nutritional quality, so they can be used as propagation material for plantlet production from mini-cuttings. Because of this possibility, clones producing mini-tubers under soilless cultivation system and with little cyclophysis effect, as was the case of the clones Macaca and SMINIA793101-3, can be a source of propagules for producing plantlets with high health quality in a practical and economical fashion.

Taking into account a plant production cycle of approximately 50 days under soilless cultivation system, the mini-cuttings required for the next planting would be obtained from plants at 30 days of cultivation. These minicuttings would be rooted in polyethylene trays, as described in this methodology, and could be irrigated only with tap water and kept in the same environment as the netted greenhouse. Thus, at the time of harvest of the mini-tubers, the plantlets would be ready for the planting of a new crop in the same production infrastructure. For clones such as Asterix, which showed a more pronounced effect of cyclophysis, mini-cuttings can be produced from newly acclimatized plants in mini-clonal hedge.

The availability of vegetative material with high quality health and the advantage of producing plantlets from plants grown under the same environmental conditions used for the production of mini-tubers are expected to overcome any differences that may be detected. It should be noted that the closed cultivation soilless system 
Table 3. Rooting percentage rate of apical mini-cuttings of young and mature plants of three potato clones.

\begin{tabular}{ccc}
\hline \multirow{2}{*}{ Clones } & \multicolumn{2}{c}{ Age of mother plant $^{*}$} \\
\cline { 2 - 3 } & Young & Mature \\
\hline Macaca & $85.0 \mathrm{aA}^{* *}$ & $31.7 \mathrm{aB}$ \\
SMINIA793101-3 & $90.0 \mathrm{aA}$ & $51.7 \mathrm{aB}$ \\
Asterix & $86.7 \mathrm{aA}$ & $8.3 \mathrm{bB}$ \\
CV (\%) & & 16.5 \\
\hline
\end{tabular}

*Mother plants were obtained from micropropagation: young were newly acclimatized plantlets, mature were at the beginning of tuberization (about 30 days after transplanting). ${ }^{* *}$ Means followed by the same letter do not differ by the Duncan test at $5 \%$ probability of error.

developed for the production of potato mini-tubers, which was used in this study, does not require the use of equipment for environmental acclimatization or plant hormones for the rooting of mini-cuttings. For this reason, it can be considered a simple, low-cost and easily applicable method at the production level. This method offers the simplifications and adaptations required to enable the small-scale production of potato plantlets and, thus, increase the availability of high quality seed potatoes.

\section{Conclusion}

Potato mini-cuttings can be rooted under closed soilless cultivation system irrigated with nutrient solution or tap water. Mini-cuttings from young plants have higher rooting capacity compared to mini-cuttings from mature plants. The loss of rooting capacity depends upon the potato cultivar.

\section{Acknowledgements}

The authors thank CAPES (Coordination for the Improvement of Higher Education Personnel) for granting research scholarship, and CNPq (National Council for Scientific and Technological Development) for partially funding the Potato Breeding and Genetics Program and for granting research scholarships.

\section{References}

[1] Assis, M. (1999) Novas Tecnologias na Propagação de Batata. Informe Agropecuário, 20, 30-33.

[2] Caldevilla, E.M. and Lozano, M.G. (1993) Cultivos Sin Suelo: Hortalizas en Clima Mediterráneo. 3rd Edición, Editorial Réus, Espanha.

[3] Medeiros, C.A.B., Ziemer, A.H. and Daniels, J. (2002) Produção de Sementes Pré-básicas de Batata em Sistemas Hidropônicos. Horticultura Brasileira, 20, 110-114. http://dx.doi.org/10.1590/S0102-05362002000100022

[4] Müller, D.R., Bisognin, D.A., Andriolo, J.L., Dellai, J. and Copetti, F. (2007) Produção Hidropônica de Batata em Diferentes Concentrações de Solução Nutritiva e Épocas de Cultivo. Pesquisa Agropecuária Brasileira, 42, 647-653. http://dx.doi.org/10.1590/S0100-204X2007000500006

[5] Dellai, J., Bisognin, D.A., Andriolo, J.L., Streck, N.A., Müller, D.R. and Bandinelli, M.G. (2008) Densidade de Plantio na Produção Hidropônica de Minitubérculos de Batata. Ciência Rural, 38, 1534-1539. http://dx.doi.org/10.1590/S0103-84782008000600007

[6] Guerra, M.P., Vesco, L.L., Pescador, R., Schuelter, A.R. and Nodari, R.O. (1999) Estabelecimento de um Protocolo Regenerativo para a Micropropagação do Abacaxizeiro. Pesquisa Agropecuária Brasileira, 34, 1557-1563. http://dx.doi.org/10.1590/S0100-204X1999000900005

[7] Silva, R.M. (1987) Multiplicação Rápida. In: Reifschneider, F.J. Org., Produção de Batata, $1^{a}$ Edição, Linha Gráfica e Editora, Brasília, 194-210.

[8] Pereira, J.E.S. and Fortes, G.R.L. (2004) Produção de Mudas Pré-Básicas de Batata por Estaquia a Partir de Plantas Micropropagadas. Horticultura Brasileira, 22, 186-192. http://dx.doi.org/10.1590/S0102-05362004000200005

[9] Silva, E.C, Pinto, C.A., Souza-Dias, J.A.C. and Araújo, T.H. (2011) Uso de Reguladores de Crescimento em Brotos Destacados de Batata-Semente. Horticultura Brasileira, 29, 504-509. http://dx.doi.org/10.1590/S0102-05362011000400010

[10] Hartmann, H.T., Kester, D.E., Davies Jr., F.T. and Geneve, R.L. (2002) Plant Propagation: Principles and Practices. 7th 
Edition, Prentice Hall, Upper Saddle River.

[11] Hackett, W.P. (1987) Donor Plant Maturation and Adventitious Root Formation. In: Davies, T.D., Haissig, B.E. and Sankhla, N., Eds., Adventitious Root Formation in Cuttings, Dioscorides Press, Portland.

[12] Bandinelli, M.G., Bisognin, D.A., Gnocato, F.S., Manbrim, R.B., Sausen, D. and Nicoloso, F.T. (2013) Concentração dos Sais e da Sacarose do Meio MS na Multiplicação in Vitro e na Aclimatização de Batata. Horticultura Brasileira, 31, 242-247. http://dx.doi.org/10.1590/S0102-05362013000200011

[13] Embrapa (1997) Centro Nacional de Pesquisa Tecnológica em Informática para Agricultura. Ambiente Software NTIA, Versão 4.2.2: Manual do Usuário, Campinas.

[14] Kibbler, H., Johnston, M.E. and Williams, R.R. (2004) Adventitious Root Formation in Cuttings of Backhousia citriodora F. Muell 1. Plant Genotype, Juvenility and Characteristics of Cuttings. Scientia Horticulturae, 102, $133-143$. http://dx.doi.org/10.1016/j.scienta.2003.12.012

[15] Dias, P.C., Oliveira, L.S., Xavier, A. and Wendling, I. (2012) Estaquia e Miniestaquia de Espécies Florestais Lenhosas do Brasil. Pesquisa Florestal Brasileira, 32, 453-462. http://dx.doi.org/10.4336/2012.pfb.32.72.453

[16] Kratz, D., Wendling, I., Brondani, G.E. and Dutra, L.F. (2010) Propagação Assexuada de Cupressus lusitanica. Pesquisa Florestal Brasileira, 30, 161-164. http://dx.doi.org/10.4336/2010.pfb.30.62.161

[17] Mckey, D., Elias, M., Pujol, B. and Duputié, A. (2010) The Evolutionary Ecology of Clonally Propagated Domesticated Plants. New Phytologist, 186, 318-332. http://dx.doi.org/10.1111/j.1469-8137.2010.03210.x

[18] Jablonka, E. and Raz, G. (2009) Transgenerational Epigenetic Inheritance: Prevalence, Mechanisms, and Implications for the Study of Heredity and Evolution. Quarterly Review of Biology, 84, 131-176. http://dx.doi.org/10.1086/598822

[19] Dellai, J. (2007) Densidade de Plantio e Poda da Parte Aérea na Partição de Massa Seca de Plantas de Batata em Hidroponia. M.Sc. Thesis, Universidade Federal de Santa Maria, Santa Maria. 
Scientific Research Publishing (SCIRP) is one of the largest Open Access journal publishers. It is currently publishing more than 200 open access, online, peer-reviewed journals covering a wide range of academic disciplines. SCIRP serves the worldwide academic communities and contributes to the progress and application of science with its publication.

Other selected journals from SCIRP are listed as below. Submit your manuscript to us via either submit@scirp.org or Online Submission Portal.
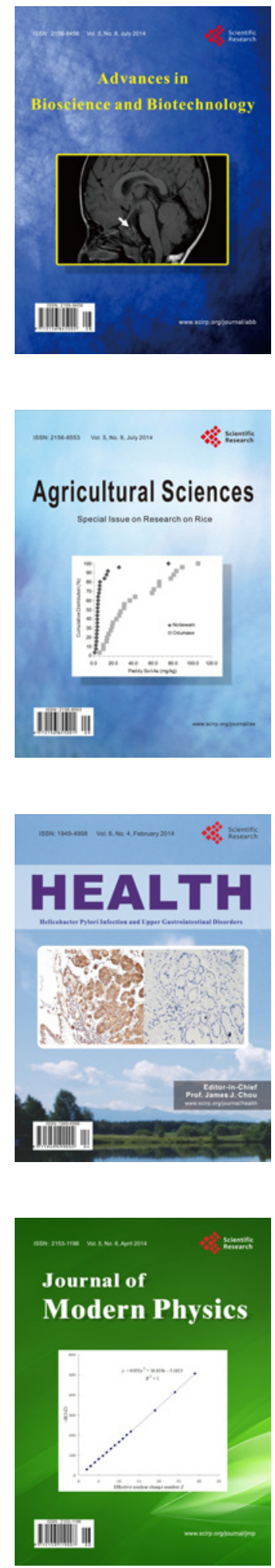


Creative Education
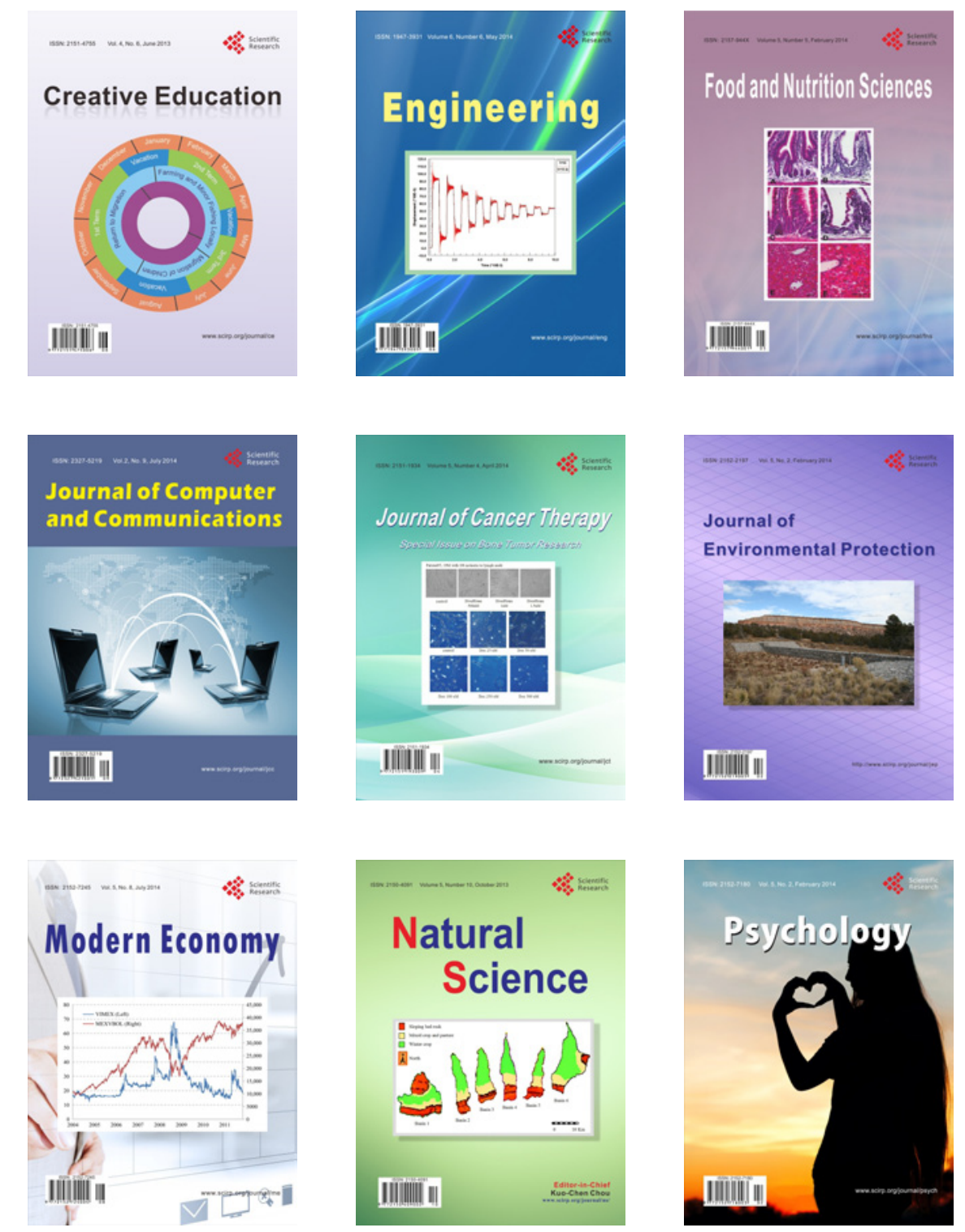